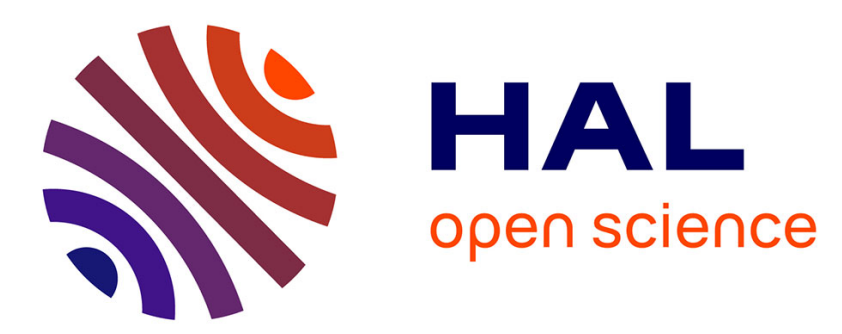

\title{
Posttranslational modifications of sickle hemoglobin in microparticles may promote injury \\ Pierre-Louis Tharaux
}

\section{To cite this version:}

Pierre-Louis Tharaux. Posttranslational modifications of sickle hemoglobin in microparticles may promote injury. Kidney International, 2019, 95, pp.1289 - 1291. 10.1016/j.kint.2019.02.023 . hal03477636

\section{HAL Id: hal-03477636 \\ https://hal.science/hal-03477636}

Submitted on 20 Dec 2021

HAL is a multi-disciplinary open access archive for the deposit and dissemination of scientific research documents, whether they are published or not. The documents may come from teaching and research institutions in France or abroad, or from public or private research centers.
L'archive ouverte pluridisciplinaire HAL, est destinée au dépôt et à la diffusion de documents scientifiques de niveau recherche, publiés ou non, émanant des établissements d'enseignement et de recherche français ou étrangers, des laboratoires publics ou privés.

\section{다)(1) $(5$}

Distributed under a Creative Commons Attribution - NonCommercial| 4.0 International 


\section{Translational Science}

\section{Post-translational modifications of sickle hemoglobin in microparticles may promote injury}

Pierre-Louis Tharaux ${ }^{1,2}$, M.D., PhD.

${ }^{1}$ Paris Cardiovascular Centre (PARCC), Institut National de la Santé et de la Recherche Médicale (INSERM), Paris, France.

2 Université Paris Descartes, Sorbonne Paris Cité, Paris, France.

Refers to: Jana S. et al. Hemoglobin oxidation-dependent reactions promote interactions with band 3 and oxidative changes in sickle cell-derived microparticles. JCI Insight. 2018: 3 (21). pii: 120451. doi: 10.1172/jci.insight.120451.

Keywords: sickle cell disease, endothelium, hemolysis, microparticles, heme, proteasome.

Sickle cell disease $(S C D)$ results from a unique mutation in the $\beta$-globin gene and is the most common genetic hemoglobinopathy. It is characterized by hemolytic anemia, painful vasoocclusive crisis and progressive organ failure including nephropathy. Red blood cells (RBCs) in patients with SCD are subjected to constant endogenous and exogenous oxidative stress, which in turn increase hemolysis and contribute to vasculopathies. A gradient of hemolysis among SCD patients influences the SCD phenotype ${ }^{1}$. Included in the vasculopathic subphenotypes associated with hyperhemolysis are pulmonary hypertension, cerebrovascular disease, leg ulcers, priapism, and sickle cell nephropathy. To what extent and how chronic hemolysis and hemoglobinuria contribute to sub-phenotypes in SCD remains unclear. A recent study by S. Jana et al. sheds light on the pathophysiological role of intracellular hemoglobin S (HbS) oxidation in RBC and RBC-derived microparticles, suggesting potential antioxidative therapies for SCD vasculopathy and nephropathy ${ }^{2}$.

Oxidized hemoglobin is toxic to endothelial cells. Outside of the protective environment of RBCs, hemoglobin is prone to oxidation, leading to the formation of oxidized hemoglobin forms. Methemoglobin (metHb) results from oxidation of the iron moieties in hemoglobin from the ferrous $(\mathrm{Fe} 2+)$ to the ferric $(\mathrm{Fe} 3+$ ) state. Ferryl hemoglobin (ferryl $\mathrm{Hb}, \mathrm{HbFe} 4+$ ) 
results from further oxidation and is highly reactive. When oxidation of hemoglobin facilitates release of its heme groups, catalytically active iron is provided to neighboring cells. Although hemoglobin is relatively innocuous to cultured endothelial cells, when oxidized to metHb it amplifies oxidant-mediated endothelial cell injury. ${ }^{4}$ Ferryl $\mathrm{Hb}$ also has proinflammatory effects on endothelial cells, an effect that is not observed with hemoglobin or metHb3.

During hemolysis, RBCs release a large number of fragments, known as microparticles. These microparticles also contain hemoglobin, but in a degraded and toxic form: the iron previously contained in the hemoglobin becomes exposed on the surface of RBC microparticles. In vitro, heme-laden RBC-derived microparticles from patients with SCD or from sickle cell mice transfer heme to cultured endothelial cells, inducing oxidative stress and apoptosis. In a mouse model of SCD that develops vaso-occlusive crisis and sickle cell nephropathy, infusion of heme-laden microparticles acutely triggered renal vaso-occlusive crisis ${ }^{4}$. The vascular effects triggered by RBC-derived microparticles were largely blocked by a heme-scavenger ${ }^{4}$.

The vaso-occlusive action of heme-laden RBC-derived microparticles, and the endotheliotoxic effect of oxidized hemoglobin forms raised the question of whether intracellular oxidation of hemoglobin takes place in the oxidative environment of SCD RBCs and microparticles and whether $\mathrm{HbS}$ would be more prone to such oxidation than $\mathrm{HbA}$.

To address this question, the Alayash laboratory monitored the kinetics of hemoglobin oxidation in RBC-derived microparticles generated from humanized mice with knock-in of normal adult hemogolobin $(\mathrm{HbA})$ or sickle $\mathrm{HbS}$. The authors focused on the intrinsic pseudoperoxidase activity of hemoglobin, which determines RBC cytosolic and membrane alterations $^{2}$. Very little spontaneous auto-oxidation of free $\mathrm{HbA}$ was observed compared to the oxidation of $\mathrm{HbS}$, suggesting a pro-oxidative milieu in the sickle cell microparticles. Ferryl $\mathrm{Hb}$ was detectable only in microparticles prepared from the humanized $\mathrm{HbS}$ mice.

When challenged with hydrogen peroxide, $\mathrm{HbS}$ is known to undergo oxidative changes affecting the structure of both the alpha and beta subunits. In the current model, challenge 
with hydrogen peroxide resulted in a marked reduction of free $\mathrm{HbS}$ subunits over a 36-hour incubation period, with no significant effect on $\mathrm{HbA}$ subunits. The observed effects were blunted in HbS mice treated with hydroxyurea, which prevents vaso-occlusive crisis and some of the chronic microvascular complications in patients with SCD. The authors also demonstrated that $\mathrm{HbS}$, especially oxidized forms, cause more damage to the endothelial monolayer than $\mathrm{HbA}$. The authors concluded that circulation of microparticles and RBCs containing highly reactive ferryl $\mathrm{Hb}$ and heme may promote vasculopathy in SCD.

The study team also demonstrated post-translational modifications of $\mathrm{HbS}$ in RBC-derived microparticles. In addition to irreversible oxidation of $\beta \mathrm{Cys} 93$, an established feature of $\mathrm{HbS}$ instability, they also observed ubiquitination of two residues of the beta globin chain. The authors hypothesized that the ubiquitination reflects proteasomal inhibition as a result of redox imbalance in sickle RBCs, although alternative hypotheses such as increased activity of the ubiquitination machinery were not fully excluded. In addition, since these observations were made following inhibition of the proteasome and deubiquitinating enzymes, the pathophysiological relevance of $\mathrm{HbS}$ ubiquitination should be addressed. Remarkably, 10 days of hydroxyurea treatment in sickle cell mice was sufficient to reverse the posttranslational alterations of $\mathrm{HbS}$ in RBC-derived microparticles, suggesting an antioxidant effect of hydroxyurea. Interestingly, chronic hydroxyurea administration is associated with a decline of albuminuria in patients with SCD. ${ }^{5}$

These findings are reminiscent of an earlier report suggesting that in addition to redox reactivity, heme may adversely alter cellular functions by binding to essential proteins and impairing their function. Demonstration of heme binding to the proteasome was actually previously linked to impaired proteasome function in Hmox1-deficient mouse embryo fibroblast cells ${ }^{6}$. Taken together, a novel model of cellular heme toxicity could be proposed, whereby proteasome inhibition by heme sustains a cycle of oxidative stress, protein modification, accumulation of damaged proteins, and cell death. Because the alterations of $\mathrm{HbS}$ were found following inhibition of the proteasome and deubiquitinating enzymes, the pathophysiological significance of ubiquitination of $\mathrm{HbS}$ should be addressed. 
The authors have nicely demonstrated that purified ferryl $\mathrm{Hb}$ can effectively promote complexes with RBC band 3 proteins, consistent with a recent study ${ }^{7}$. Oxidation of $\mathrm{HbS}$ generates products with high affinity toward the cytoplasmic domain of band 3 and is reported to mediate oxidative crosslinking ${ }^{8}$. Band 3 clustering causes RBC membrane alterations that may promote microparticle generation, and may be involved in kidney vasoocclusion ${ }^{9}$. We previously found that microparticles derived from sickle cell RBCs but not from normal RBCs triggered renal vaso-occlusive crisis in mice. We also observed hemoglobin accumulation within tubulo-interstitial and glomerular capillaries in kidney biopsies from patients with SCD, suggesting a pathological role in the progression of sickle cell nephropathy ${ }^{9}$. We hypothesize that transfer of cytotoxic microparticles to the glomerular endothelium may also contribute to severe endothelial dysfunction or exposure of the subendothelial matrix in a subset of patients who suffer from severe SCD nephropathy with features of glomerular thrombotic microangiopathy. By demonstrating that $\mathrm{HbS}$, especially the oxidized forms, can cause more damage to endothelial monolayer than $\mathrm{HbA}$, the study by Jana et al. adds further mechanistic evidence that such action involves microparticle-borne ferryl $\mathrm{HbS}$ with post-translational modifications.

Overall, this novel work suggests a potential role for intracellular HbS oxidation in RBCs and RBC-derived microparticles in promoting the vascular complications of SCD. Anti-oxidant interventions may limit hemoglobin oxidation in SCD RBCS and RBC-derived microparticles, offering a potential therapeutic approach to prevent or mitigate SCD vasculopathy and hopefully sickle cell nephropathy.

\section{Disclosure}

The author has nothing to declare.

\section{References}

1. Kato GJ, Steinberg MH, Gladwin MT. Intravascular hemolysis and the pathophysiology of sickle cell disease. The Journal of clinical investigation 2017; 127: 750-760.

2. Jana S, Strader MB, Meng F, et al. Hemoglobin oxidation-dependent reactions promote interactions with band 3 and oxidative changes in sickle cell-derived microparticles. JCI insight 2018; 3. 
3. Balla J, Jacob HS, Balla G, et al. Endothelial-cell heme uptake from heme proteins: induction of sensitization and desensitization to oxidant damage. Proceedings of the National Academy of Sciences of the United States of America 1993; 90: 9285-9289.

4. Camus SM, De Moraes JA, Bonnin P, et al. Circulating cell membrane microparticles transfer heme to endothelial cells and trigger vasoocclusions in sickle cell disease. Blood 2015; 125: 3805-3814.

5. Bartolucci P, Habibi A, Stehle T, et al. Six months of hydroxyurea reduces albuminuria in patients with sickle cell disease. JASN 2016; 27: 1847-1853.

6. Vallelian F, Deuel JW, Opitz L, et al. Proteasome inhibition and oxidative reactions disrupt cellular homeostasis during heme stress. Cell death and differentiation 2015; 22: 597-611.

7. Welbourn EM, Wilson MT, Yusof A, et al. The mechanism of formation, structure and physiological relevance of covalent hemoglobin attachment to the erythrocyte membrane. Free radical biology \& medicine 2017; 103: 95-106.

8. Walder JA, Chatterjee R, Steck TL, et al. The interaction of hemoglobin with the cytoplasmic domain of band 3 of the human erythrocyte membrane. The Journal of biological chemistry 1984; 259: 10238-10246.

9. Camus SM, Gausseres B, Bonnin P, et al. Erythrocyte microparticles can induce kidney vaso-occlusions in a murine model of sickle cell disease. Blood 2012; 120: 5050-5058.

9. Bartolucci P, Habibi A, Stehle T, et al. Six Months of Hydroxyurea Reduces Albuminuria in Patients with Sickle Cell Disease. Journal of the American Society of Nephrology : JASN 2016; 27: 1847-1853. 